\title{
Dry matter and nitrogen allocation in western redcedar, western hemlock, and Douglas fir seedlings grown in low- and high- $\mathbf{N}$ soils 1
}

\author{
Joseph E. Graff, Jr ${ }^{*}$, Richard K. Hermann, Joe B. Zaerr \\ Department of Forest Science, Oregon State University, Corvallis, OR 97331, USA
}

(Received 28 October 1998; accepted 7 June 1999)

\begin{abstract}
Seedlings of western red cedar (Thuja plicata Donn ex. D. Don), western hemlock (Tsuga heterophylla (Raf.) Sarg.), and Douglas fir (Pseudotsuga menziesii (Mirb.) Franco) were transplanted into each of 48 pots with soils of low or high levels of available $\mathrm{NO}_{3}^{-}$(and total $\mathrm{N}$ ) and assigned to one of four treatments: unamended control; amendment with $60 \mathrm{mg} \mathrm{kg}^{-1}\left(\mathrm{NH}_{4}\right)_{2} \mathrm{SO}_{4}$; amendment with $15 \mathrm{mg} \mathrm{kg}^{-1}$ of the nitrification inhibitor dicyandiamide (DCD) or amendment with both $\left(\mathrm{NH}_{4}\right)_{2} \mathrm{SO}_{4}$ and $\mathrm{DCD}$. Dry weight and $\mathrm{N}$ content increments of seedling tissues were determined after 8 weeks. Seedlings grown on the low-N soil accumulated $65 \%$ of the dry matter and $40 \%$ of the $\mathrm{N}$ accumulated by seedlings grown on the high- $\mathrm{N}$ soil. Retranslocation of $\mathrm{N}$ from year-old foliage and the stem/branch components of western red cedar and Douglas fir, but not western hemlock, was an important source of $\mathrm{N}$ for current-year foliage and roots of low-N-grown seedlings. Western hemlock achieved the greatest relative dry-matter increment $\left(\log _{e}\left(D M_{\text {final }}\right)-\log _{e}\left(D M_{\text {initial }}\right) ; R D M I\right)$ and relative $N$ increment $\left(\log _{c}\left(N_{\text {final }}\right)-\log _{e}\left(N_{\text {initial }}\right)\right.$; RNI) in each soil and accumulated $35 \%$ more $\mathrm{N}$ from the low-N and $10 \%$ more $\mathrm{N}$ from the high-N soils than the other species. The RDMI of western red cedar was intermediate between that of western hemlock and Douglas fir, whereas its RNI on each of the soils was lowest. The results suggest that western hemlock is more efficient than western red cedar or Douglas fir in acquiring inorganic N, especially from low-N soils. (C) 1999 Éditions scientifiques et médicales Elsevier SAS.
\end{abstract}

foliage mass / root / nitrogen content / relative dry matter increment / retranslocation

Résumé - Matière sèche et allocation de l'azote dans des semis de Thuja plicata, Tsuga heterophylla et Douglas poussant en condition de sols pauvres et riches en azote. Des semis de Thuja plicata Don ex. D. Don, de Tsuga heterophylla (Raf.) Sarg et de Douglas (Pseudotsuga menziesii (Mirb.) Franco) ont été replantés dans 48 pots contenant du sol avec des quantités faibles ou élevées de nitrate $\mathrm{NO}_{3}^{-}$(et d'azote total) selon 4 traitements : témoin sans apport, fertilisé avec $60 \mathrm{mg} \mathrm{kg}^{-1}$ de $\left(\mathrm{NH}_{4}\right) 2 \mathrm{SO}_{4}$, un apport de $15 \mathrm{mg}$ $\mathrm{kg}^{-1}$ de dicyandiamide (DCD) un inhibiteur de la nitrification, un traitement combiné avec $60 \mathrm{mg} \mathrm{kg}^{-1}$ de $\left(\mathrm{NH}_{4}\right) 2 \mathrm{SO}_{4}$ et le DCD.

Le poids sec et le contenu en azote des tissus des semis ont été déterminés après 8 semaines. Les semis du traitement à faibles réserves en azote assimilable ont accumulé $65 \%$ de matière sèche et $40 \%$ de l'azote relativement au traitement à haut niveau d'azote. Le transfert interne d'azote depuis les aiguilles d'un an et les compartiments du tronc et des branches chez le Thuja et le Douglas, mais pas pour le Tsuga, est une importante source d'azote pour la croissance des aiguilles et racines de l'année dans le traitement le plus pauvre en azote. Le Tsuga présente l'accroissement relatif le plus élevé en matière sèche $\left(\log _{\mathrm{e}}\left(\mathrm{DM}_{\text {final }}\right)-\log _{\mathrm{e}}\left(\mathrm{DM}_{\text {initial }}\right)=\right.$ RDMI) et en azote $\left(\log _{e}\left(N_{\text {final }}\right)-\log _{c}\left(N_{\text {intial }}\right)=R N I\right)$ pour chacun des traitements et a accumulé $35 \%$ d'azote en plus pour le traitement faible et $10 \%$ en plus pour le traitement élevé que les autres espèces. Le RDMI du Thuja est intermédiaire entre celui du Tsuga et du Douglas, alors que son RNI est le plus faible quel que soit le sol. Les résultats suggèrent que le Tsuga est plus efficient que le Thuja ou le Douglas pour l'absorption d'azote inorganique, spécialement dans les sols pauvres en azote. (C) 1999 Éditions scientifiques et médicales Elsevier SAS.

masse foliaire / racine / concentration en azote / accroissement relatif en matière sèche / transfert interne

\footnotetext{
'This is Paper 3128 of the Forest Research Laboratory, Oregon State University, Corvallis, OR 97331, USA

* Correspondance and reprints graffjoe@aol.com.
} 


\section{Introduction}

Western red cedar (Thuja plicata Donn ex D. Don), western hemlock (Tsuga heterophylla (Raf.) Sarg.), and Douglas fir (Pseudotsuga menziesii (Mirb.) Franco) are dominant tree species in plant associations throughout the Pacific Northwest. The species are associated with each other across a range of soils that vary greatly with respect to physical and chemical properties [28, 29, 33]. The organic horizons and upper $15 \mathrm{~cm}$ of mineral soil beneath western red cedar are characterized by higher $\mathrm{pH}$, higher base saturation (attributable especially to $\mathrm{Ca}$ ), and larger bacterial populations than the soil horizons beneath western hemlock $[1,32]$. The $\mathrm{pH}$ and $\mathrm{Ca}$ concentrations of litter and soil tend to be highest for western red cedar, lowest for western hemlock, and intermediate for Douglas fir $[1,12]$. High rates of nitrification have been observed beneath western red cedar, whereas it has been suggested that western hemlock actively inhibits nitrification $[32,33]$. An exception to these generalizations may explain the poor response of western red cedar to increases in nutrient availability at northern latitudes in coastal British Columbia [22]. There, western red cedar and western hemlock occur on soils overlaid by deep organic horizons on sites characterized as $\mathrm{N}$-limiting (e.g. soils with high $\mathrm{C} / \mathrm{N}$ ratio and lack of detectable $\mathrm{NO}_{3}^{-}-\mathrm{N}$ ) [23]. Messier [22] reported that removal of competing vegetation increased $\mathrm{N}$ and $\mathrm{P}$ availability by up to $40 \%$ and that western hemlock and Sitka spruce (Picea sitchensis (Bong.) Carr.), but not western red cedar, responded with increased growth relative to control seedlings. Messier [22] used mixed ion exchange resins to monitor $\mathrm{N}$ availability and noted that extractable $\mathrm{NH}_{4}$ increased by $22-40 \%$ after removal of competing vegetation, but that extractable $\mathrm{NO}_{3}$ was negligible for both treatments.

On the basis of studies of seedlings grown in sandy soils, Krajina et al. [21] and Gijsman [13] have suggested that western red cedar and Douglas fir prefer $\mathrm{NO}_{3}^{-}-\mathrm{N}$ rather than $\mathrm{NH}_{4}{ }^{+}-\mathrm{N}$. In contrast, greater dry matter production with $\mathrm{NH}_{4}{ }^{+} \mathrm{N}[21,34]$ has been reported for western hemlock [21, 34] and Douglas fir [3]. These observations seem consistent with two different mechanisms of $\mathrm{N}$ nutrition, i.e. preference for $\mathrm{NO}_{3}^{-}-\mathrm{N}$ by western red cedar and preference for $\mathrm{NH}_{4}{ }^{+}-\mathrm{N}$ by western hemlock. Soil chemistry beneath Douglas fir can generally be characterized as intermediate to the conditions beneath western red cedar and western hemlock $[1,33]$. The relatively poor performance of $\mathrm{NH}_{4}{ }^{+}$-grown western red cedar and Douglas fir reported in Krajina et al. [21] may have been due to the presence of excess chloride; the final $\mathrm{Cl} / \mathrm{N}$ ratio was approximately $4: 1$ when $\mathrm{N}$ was added as $\mathrm{NH}_{4} \mathrm{Cl}$, but was $<1: 28$ when $\mathrm{N}$ was added as $\mathrm{KNO}_{3}$.

This study was designed to repeat the experiment of Krajina et al. [21] without imposing the potentially negative effects of chloride. In addition, the three species were placed together in each pot, rather than in separate pots. The objective was to compare the dry-matter increment and $\mathrm{N}$ accumulation (uptake and retranslocation) of western red cedar, western hemlock, and Douglas fir on two soils characterized by low and high $\mathrm{N}$ availability and, respectively, negligible or rapid nitrification.

\section{Methods}

\subsection{Site and soil descriptions}

Two soils representative of low- and high- $\mathrm{N}$ status were collected in early May from the upper $15 \mathrm{~cm}$ of the A horizon at two locations. The nitrogen-deficient Wind River soil (designated here as "low-N soil") was obtained from site IV land adjacent to a Douglas fir spacing trial established in 1925 near Carson, Washington. Curtis and Reukema [11] describe the soil as "a loose sandy loam with sporadic admixture of basaltic gravel and cobble developing on pumiceous alluvium underlain by lightly fractured basaltic rock". A fire in 1924 consumed much of the duff and debris, exposing mineral soil. The intensity of the burn led to formation of extremely stable soil aggregates that comprise approximately $20 \%$ of the soil mass. The area is currently occupied by a 60-year-old stand of Douglas fir; associated vegetation is typical of the PSME/GASH community type (Pseudotsuga menziesii/Gaultheria shallon Pursh) [10].

The nitrogen-rich Cascade Head soil (designated "high-N soil") was obtained near the Oregon coast in a 45-year-old ALRU/RUSP/POMU community type (Alnus rubra Bong./Rubus spectabilis Pursh/Polystichum munitum (Kaulf.) Presl.) [10] dominated by Pseudotsuga menziesii, A. rubra, and Picea sitchensis. The soil is an organically rich silt to silty clay loam Typic Dystrandept, most likely of the Hembre or Astoria series [5].

At the two sites, the soils were pushed through a large-framed 4-mm sieve as they were collected in order to remove coarse material and plant roots. Nylon feed bags were used to transport the soils to the Oregon State University (OSU) campus, where they were stored in a cold room at $4{ }^{\circ} \mathrm{C}$ for a week until seedlings were delivered. Samples of the soils were taken immediately for determination of soil $\mathrm{C}$ and $\mathrm{N}$ content, mineralizable $\mathrm{N}$, potential $\mathrm{N}$ mineralization and nitrification, and $\mathrm{pH}$. 


\subsection{Soil chemical analyses and incubations}

Chemical properties of the soils were determined by the following methods: soil $\mathrm{pH}$ at a soil/distilled-deionized water $\left(\mathrm{H}_{2} \mathrm{O}_{\mathrm{dd}}\right)$ ratio of $1: 2\left(\mathrm{~g} \mathrm{~g}^{-1}\right)$; total $\mathrm{N}$ by Kjeldahl digestion; mineralized $\mathrm{NH}_{4}{ }^{+}$and $\mathrm{NO}_{3}{ }^{-}$by extraction from soil with $2 \mathrm{M} \mathrm{KCl}$ [19]; and organic $\mathrm{C}$ by combustion of soil samples in a LECO 12 carbon analyzer. Laboratory incubations were used to determine potential $\mathrm{N}$ mineralization and nitrification of the two soils. Sixty 20-g (oven-dried basis) samples of field-moist soil were incubated in 100-mL-capacity specimen cups with lids. Samples of each soil were assigned randomly to one of two treatments: i) control, or ii) amendment with $77 \mathrm{mg} \mathrm{N} \mathrm{kg}^{-1}$ as $\left(\mathrm{NH}_{4}\right)_{2} \mathrm{SO}_{4}$. A stock solution of $\left(\mathrm{NH}_{4}\right)_{2} \mathrm{SO}_{4}$ was prepared $\left(3.51 \mathrm{~g} \mathrm{~N} \mathrm{~L}^{-1}\right)$. Four milliliters of $\mathrm{H}_{2} \mathrm{O}_{\mathrm{dd}}$ or $2 \mathrm{~mL}$ each of $\mathrm{H}_{2} \mathrm{O}_{\text {dd }}$ and the stock solution were applied to the surface of the soil in the cups. Additional $\mathrm{H}_{2} \mathrm{O}_{\mathrm{dd}}$ was added to bring the soils to field capacity (gravimetric water content: $0.31 \mathrm{~g} \mathrm{~g}^{-1}$ low-N soil; $0.55 \mathrm{~g} \mathrm{~g}^{-1}$ high-N soil). Samples were incubated in the dark at $25^{\circ} \mathrm{C}$, aerated daily, and weighed at 3- or 4day intervals. Water was added as needed to maintain the original mass. Twelve samples - three randomly selected replicates from each of the four soil by $\mathrm{N}$ amendment treatments - were extracted with $50 \mathrm{~mL}$ of $2 \mathrm{M} \mathrm{KCl}$ at 3 , $7,21,35$, and 49 days. Solution concentrations of $\mathrm{NH}_{4}^{+}-$ $\mathrm{N}$ and $\mathrm{NO}_{3}{ }^{-} \mathrm{N}$ were determined on an autoanalyzer (Scientific Instruments CFA 200) by the Soil Testing $\mathrm{Lab}$ at $\mathrm{OSU}\left(\mathrm{NH}_{4}{ }^{+}\right.$by salicylate/nitroprusside; $\mathrm{NO}_{3}{ }^{-}$by diazotization following $\mathrm{Cd}$ reduction).

\subsection{Growth chamber study}

Three 1-year-old plug seedlings of each species (western red cedar, western hemlock, and Douglas fir) were planted in 48 paper pots $(30.5 \mathrm{~cm}$ lip diameter by $46 \mathrm{~cm}$ deep), with 24 of the pots containing low-N soil and 24 high-N soil. To minimize variation attributable to soil heterogeneity and seedling interspecific competition, the trees were positioned with a circular template such that one member of each species was planted for each of the three triangular pie-shaped subdivisions within each pot (three seedlings of each species per pot). Distilled water or ammonium sulfate $\left(60 \mathrm{mg} \mathrm{N} \mathrm{kg} \mathrm{N}^{-1}\right.$ ) was applied in solution to the surface of the soil of half of the pots in both the low-N and high-N soils. The nitrification inhibitor dicyandiamide (DCD) was applied in solution to the surface of the soil of half of the pots of each soil by $\mathrm{N}$ amendment treatment to establish concentrations of 0 or $15 \mathrm{mg}$ DCD-N kg-1. The stock solutions or distilled water were allowed to percolate in before more water was added to bring the soils to field capacity. Six repli- cations were assembled for each treatment. Forest soils and $\left(\mathrm{NH}_{4}\right)_{2} \mathrm{SO}_{4}$ were used to prevent possible effects of chloride on seedling growth or on the inorganic cationminus-anion balance; these problems were inherent in an earlier study [21] where $\mathrm{N}$ was applied as $\mathrm{NH}_{4} \mathrm{Cl}$ to a sandy soil. The pots were randomly positioned in a growth chamber with $16-\mathrm{h}$ photo-period, $140 \mu \mathrm{mol} \mathrm{m} \mathrm{m}^{-2}$ $\mathrm{s}^{-1}, 20^{\circ} \mathrm{C}$ day (relative humidity $45 \%$ ): $15^{\circ} \mathrm{C}$ night. Approximately $1.5 \mathrm{~L}$ of water were applied to the soil in each pot every third day to maintain the soil moisture levels near field capacity.

After 8 weeks, seedlings from three of the six replicate pots for each treatment were sampled for dry matter and $\mathrm{N}$. The three seedlings of the same species within each pot were pooled, and after their roots were carefully rinsed free of soil, seedlings were cut at the cotyledon scar. Roots were then blotted dry, weighed, and immediately placed in a $70^{\circ} \mathrm{C}$ oven for $72 \mathrm{~h}$. Shoots were stored at $4{ }^{\circ} \mathrm{C}$ for up to 1 week while each sample was separated into current-year foliage, old foliage, and stems/branches. These component tissues were ovendried at $70^{\circ} \mathrm{C}$ and weighed for determination of dry matter. Current-year foliage of western red cedar was more succulent and paler than year-old foliage. Juvenile leaves, which occur in whorls on the stem and branches of western red cedar, were included in the stem/branch component. The current-year and year-old foliage components of western hemlock and Douglas fir were easily distinguished by the presence of bud scars on the stems and branches. Four three-tree sets of each species were destructively sampled at the outset of the study for determination of fresh and dry weight of foliage, stem/branch, and root components (table I). Subsequently all tissues were redried, ground in a Wiley mill (20 mesh), and subjected to modified Kjeldahl digestion [6] to allow determination of their $\mathrm{N}$ concentrations.

At 10 weeks, the current-year foliage of seedlings from the second set of three replicate pots per treatment was sampled for organic acid content and inorganic cations and anions. The results of that portion of the study are reported in a second paper [15].

\subsection{Statistical analyses}

Treatment effects for this split-plot experiment were analyzed by using PROC MIXED in SAS 6.10 with soil as the main plot, $\mathrm{N}$ and DCD amendments as sub-plots, and species as sub-sub-plots [30]. If the whole-plot mean square error term (soil) was smaller than the sub-plot mean square error term (species and $\mathrm{N}$ amendment), the whole-plot error term was removed from the model and the whole-plot effects were tested with the larger sub- 
Table I. Initial dry weights, $\mathrm{N}$ concentrations, and $\mathrm{N}$ contents of western redcedar, western hemlock, and Douglas-fir seedlings ${ }^{\mathrm{a}}$.

\begin{tabular}{|c|c|c|c|}
\hline Variable & Western redcedar & Western hemlock & Douglas fir \\
\hline Total dry weight (g) & $3.62(0.47)^{\mathrm{b}}$ & $2.24(0.34)$ & $4.42(0.32)$ \\
\hline Foliage & $0.96(0.25)$ & $1.25(0.20)$ & $1.67(0.08)$ \\
\hline Roots & $1.33(0.16)$ & $0.55(0.10)$ & $1.90(0.18)$ \\
\hline Leaf weight ratio ${ }^{c}\left(g_{\text {foliagc }} g_{\text {total mass }}{ }^{-1}\right)$ & $0.23(0.09)$ & $0.54(0.05)$ & $0.38(0.02)$ \\
\hline Shoot:root ratio $\left(\mathrm{g} \mathrm{g}^{-1}\right)$ & $1.72(0.09)$ & $3.07(0.35)$ & $1.32(0.08)$ \\
\hline Whole plant $\mathrm{N}(\mathrm{mg})$ & $81(10)$ & $38(6)$ & $50(2)$ \\
\hline Leaf $\mathrm{N}$ ratio ${ }^{\mathrm{c}}$ & $0.33(0.08)$ & $0.62(0.09)$ & $0.47(0.04)$ \\
\hline
\end{tabular}

${ }^{a}$ Means of four randomly selected sets of three seedlings of each species at time of planting into pots.

bNumber in parentheses is the standard error of the mean.

'Leaf weight ratio (leaf $\mathrm{N}$ ratio) is the proportion of total seedling mass ( $\mathrm{N}$ content) contributed by foliage.

plot error term [24]. The initial analyses revealed that the DCD had no statistically significant effect on any variable. In addition, concurrently established incubations of the high- $\mathrm{N}$ soil with $15-90 \mathrm{mg} \mathrm{DCD} \mathrm{kg}{ }^{-1}$ failed to alter the rate of $\mathrm{NO}_{3}^{-}-\mathrm{N}$ production in the high- $\mathrm{N}$ soil (data not presented). Therefore, the DCD fixed effect was removed from the analyses and the data were reanalyzed with 12 replications per soil by $\mathrm{N}$ treatment with only the $\mathrm{N}$ fixed effect as a sub-plot. Comparisons of means were based on the F statistics generated in PROC MIXED: comparisons attributable to single-factor effects were compared only if the interaction effects were not statistically significant [30].

Dry matter (growth) and $\mathrm{N}$ increments (change from initial to final values) for whole seedlings and their individual tissue components ( 1 -year-old foliage, total foliage, stem and branches, roots) were analyzed. In addition, relative dry-matter increment (RDMI) and relative $\mathrm{N}$ increment (RNI) were evaluated after $\log _{\mathrm{e}}$ transformations of the ratio of final dry weight (at 8 weeks) to initial dry weight (e.g. RDMI $=\log _{\mathrm{e}}\left(\mathrm{DM}_{\text {final }}\right)-\log _{\mathrm{e}}$ $\left(D_{\text {initial }}\right) ; R N I=\log _{e}\left(N_{\text {final }}, x\right)-\log _{e}\left(N_{\text {initial }}\right)$, where $x$ refers to the whole plant or a component part). The transformations were performed in order to account for initial differences in weight and $\mathrm{N}$ content among species raised under different nursery regimes. Comparison of means was made with the transformed data. Values reported for RDMI and RNI are the result of back-transformation of the logarithms of each ratio minus 1 .

\section{Results}

\subsection{Soil chemical properties}

Chemical properties of the soils, including concentrations of $\mathrm{C}$ and $\mathrm{N}$ and of extractable and potentially mineralizable $\mathrm{NH}_{4}{ }^{+}-\mathrm{N}$ and $\mathrm{NO}_{3}^{-}-\mathrm{N}$, are included in table II. The $\mathrm{C} / \mathrm{N}$ ratios are relatively low for both soils (table $I I$ ), suggesting active $\mathrm{N}$ mineralization. The exceptionally low $\mathrm{C}$ and $\mathrm{N}$ values in the low-N soil reflect a low organic-matter content that is consistent with the fire history at the Douglas fir spacing trial site. The low- $\mathrm{N}$ soil maintained a mineralization rate that was only $18.5 \%$ of that in the high- $\mathrm{N}$ soil during the first 21 days of incubation (table II). Little or no nitrification occurred in the low- $\mathrm{N}$ soil, and the concentration of $\mathrm{NH}_{4}{ }^{+}$was stable in the unamended low- $\mathrm{N}$ soil from day 21 to day 49 [15]. Mineralization of $\mathrm{N}$ from the high- $\mathrm{N}$ soil was sustained continuously at a rate of approximately $1.5 \mathrm{mg} \mathrm{N} \mathrm{kg}^{-1}$ day $^{-1}$ through 49 days [15]; more than $85 \%$ of the $\mathrm{N}$ mineralized was present as nitrate. Two-thirds of the $\mathrm{N}$ added to the soils was immobilized by the soil biomass, and $\mathrm{NO}_{3}{ }^{-}$production was not stimulated by the addition of $\mathrm{NH}_{4} \mathrm{SO}_{4}$ in the low- $\mathrm{N}$ soil, whereas amendment $\mathrm{N}$ was rapidly nitrified in high-N soil (table II).

\subsection{Dry matter and $\mathbf{N}$ increments}

Only the dry matter increments of current-year foliage and the final nitrogen concentrations of the whole plants, current-year foliage, year-old foliage, and root components were significantly affected by the interaction of the 
Table II. Chemical properties of the low-N (Wind River) and high-N (Cascade Head) soils.

\begin{tabular}{|c|c|c|}
\hline Property & Low-N soil & High-N soil \\
\hline Total carbon $\left(\mathrm{mg} \mathrm{g}^{-1}\right)$ & 15 & 137 \\
\hline Total nitrogen $\left(\mathrm{mg} \mathrm{g}^{-1}\right)$ & 0.7 & 10.7 \\
\hline $\mathrm{C}: \mathrm{N}$ & 20.8 & 12.8 \\
\hline Extractable $\mathrm{NH}_{4}^{+}\left(\mathrm{mg} \mathrm{kg}^{-1}\right)$ & 0.19 & 0.77 \\
\hline Extractable $\mathrm{NO}_{3}^{-}\left(\mathrm{mg} \mathrm{kg}^{-1}\right)$ & 0.01 & 11.0 \\
\hline $\begin{array}{l}\text { Nitrogen mineralization } \\
\left(\mathrm{mg} \mathrm{N} \mathrm{kg-1} \mathrm{day}^{-1}\right)^{\mathrm{a}}\end{array}$ & 0.37 & 2.00 \\
\hline Nitrification $\left(\mathrm{mg} \mathrm{N} \mathrm{kg}^{-1} \mathrm{day}^{-1}\right)^{\mathrm{a}}$ & 0.001 & 1.73 \\
\hline $\mathrm{N}$-mineralization (N-amended soil) ${ }^{\mathrm{a}}$ & 1.11 & 2.68 \\
\hline Nitrification $\left(\mathrm{N}\right.$-amended soil) ${ }^{\mathrm{a}}$ & 0.001 & 2.31 \\
\hline
\end{tabular}

Rates of nitrogen mineralization and nitrification from native and $\mathrm{N}$ amended soils $\left(77 \mathrm{mg} \mathrm{kg}^{-1}\left(\mathrm{NH}_{4}\right)_{2} \mathrm{SO}_{4}\right)$ incubated for 21 days in the laboratory. Soil moisture was maintained at field capacity $\left(0.31 \mathrm{~g} \mathrm{~g}^{-1}\right.$ (low-N soil) and $0.55 \mathrm{~g} \mathrm{~g}^{-1}$ (high- $\mathrm{N}$ soil)). The concentration of nitrate in the low- $\mathrm{N}$ soil did not exceed $0.6 \mathrm{mg} \mathrm{kg}^{-1}$.

soil and species (table $I I I)$. Dry matter and $\mathrm{N}$ increments for whole plants and the root component were affected only by single fixed effects (soil or species). Amendment of the two soils with $60 \mathrm{mg} \mathrm{kg}^{-1}\left(\mathrm{NH}_{4}\right)_{2} \mathrm{SO}_{4}-\mathrm{N}$ had small effects on $\mathrm{N}$ concentration of whole seedlings and their component tissues (increased by $<10 \%$; difference not significant statistically), but no differences were found in dry matter production either via interaction effects or single factor effects associated with $\mathrm{N}$ amendment.

Regardless of species, seedlings grown on the high-N soil produced more current-year foliage than seedlings grown on low-N soil (table III). Significant differences in current-year foliage increments between species were apparent only for the low-N soil: western red cedar produced $54 \%$ more current-year foliage on a dry-matter basis than Douglas fir (table III). With regard to $\mathrm{N}$ concentration, for each component where significant differences were observed, western red cedar grown on the high-N soil had the highest $\mathrm{N}$ concentrations and Douglas fir grown on low-N soil had the lowest (table III).

Seedlings grown on the low- $\mathrm{N}$ soil accumulated only $53-85 \%$ of the dry matter and 71-91\% of the $\mathrm{N}$ of seedlings grown on the high- $\mathrm{N}$ soil during the 8-week trial (table III). In low- $\mathrm{N}$ soil, foliar $\mathrm{N}$ concentrations for western red cedar, western hemlock, and Douglas fir (table III) were characteristic, respectively, of the "slight moderate", "nearly adequate", and "severe" deficiency classifications of Ballard and Carter [2]. In high-N soil, in contrast, concentrations of $\mathrm{N}$ in current-year foliage (table III) were higher than critical values described as adequate [2]. Differences in growth of seedlings planted in low- and high-N soils (table III) were attributable entirely to soil $\mathrm{N}$ status. Clearly, $\mathrm{N}$ availability was not limiting to seedling growth in the high- $\mathrm{N}$ soil. Increases in foliage biomass contributed $35 \%$ of the overall change in seedling dry matter weight for the low- $\mathrm{N}$ and $43 \%$ for the high-N seedlings (table III). Plants in low$\mathrm{N}$ soil had nearly equivalent weights of new and old foliage (1:1 ratio, table III), whereas seedlings potted in high- $\mathrm{N}$ soil nearly tripled their foliage weights during the 8 -week study (2:1 new-to-old foliage ratio). More than $50 \%$ of the total $\mathrm{N}$ increase was accumulated in currentyear foliage (table III).

Western hemlock had the greatest leaf weight ratio $\left(\mathrm{g}_{\text {foliage }} \mathrm{g}_{\text {total }}{ }^{-1}\right)$ of the three species at the conclusion of the study (table III). Dry matter increments of the three species were significantly different on the basis of whole plants (western hemlock > western redcedar > Douglas fir), year-old foliage (redcedar, hemlock $>$ Douglas fir), and roots (hemlock $>$ redcedar, Douglas fir) (table III). The mass of current-year foliage produced during the study did not differ among species in the high-N soil, but was greater for western red cedar than Douglas fir in the low-N soil (table III). The RDMI of western red cedar was only about $60 \%$ of that of western hemlock (table IV), despite the latter's initially smaller dry weight (table I). The RDMI of Douglas fir was equally small (table IV).

Overall, western hemlock accumulated $35 \%$ more $\mathrm{N}$ from the low- $\mathrm{N}$ soil and $10 \%$ more from the high-N soil than either western red cedar or Douglas fir (table III). The $\mathrm{N}$ increments from the high- $\mathrm{N}$ soil were nearly equivalent for the three species (table III). However, assessment of $\mathrm{N}$ increment with respect to initial $\mathrm{N}$ content showed that the RNI of western hemlock was significantly greater than that of western red cedar and Douglas fir (table IV) and that hemlock made up $50 \%$ of its initial $\mathrm{N}$ content difference with red cedar (table I). The $\mathbf{N}$ increment of the year-old foliage component was positive in western red cedar and western hemlock on high- $\mathrm{N}$ soil, but negative in all three species on low- $\mathrm{N}$ soil and in Douglas fir on high-N soil (table III). The $\mathrm{N}$ increment of the stem/branch component of western red cedar was negative on both soils during the study (table III). There were no differences among the species in the proportional allocation of dry matter or $\mathrm{N}$ to shoots and roots. More than $67 \%$ of the dry matter increment and $60 \%$ of the $\mathrm{N}$ increment was accumulated in the shoots (table III). The leaf $\mathrm{N}$ ratios (leaf $\mathrm{N}$ content/whole plant $\mathrm{N}$ content) of western red cedar and western hemlock were greater than those of Douglas fir (table III). 
Table III. Final dry weight and nitrogen content, and dry matter and nitrogen increments, of whole seedlings and their component tissues.

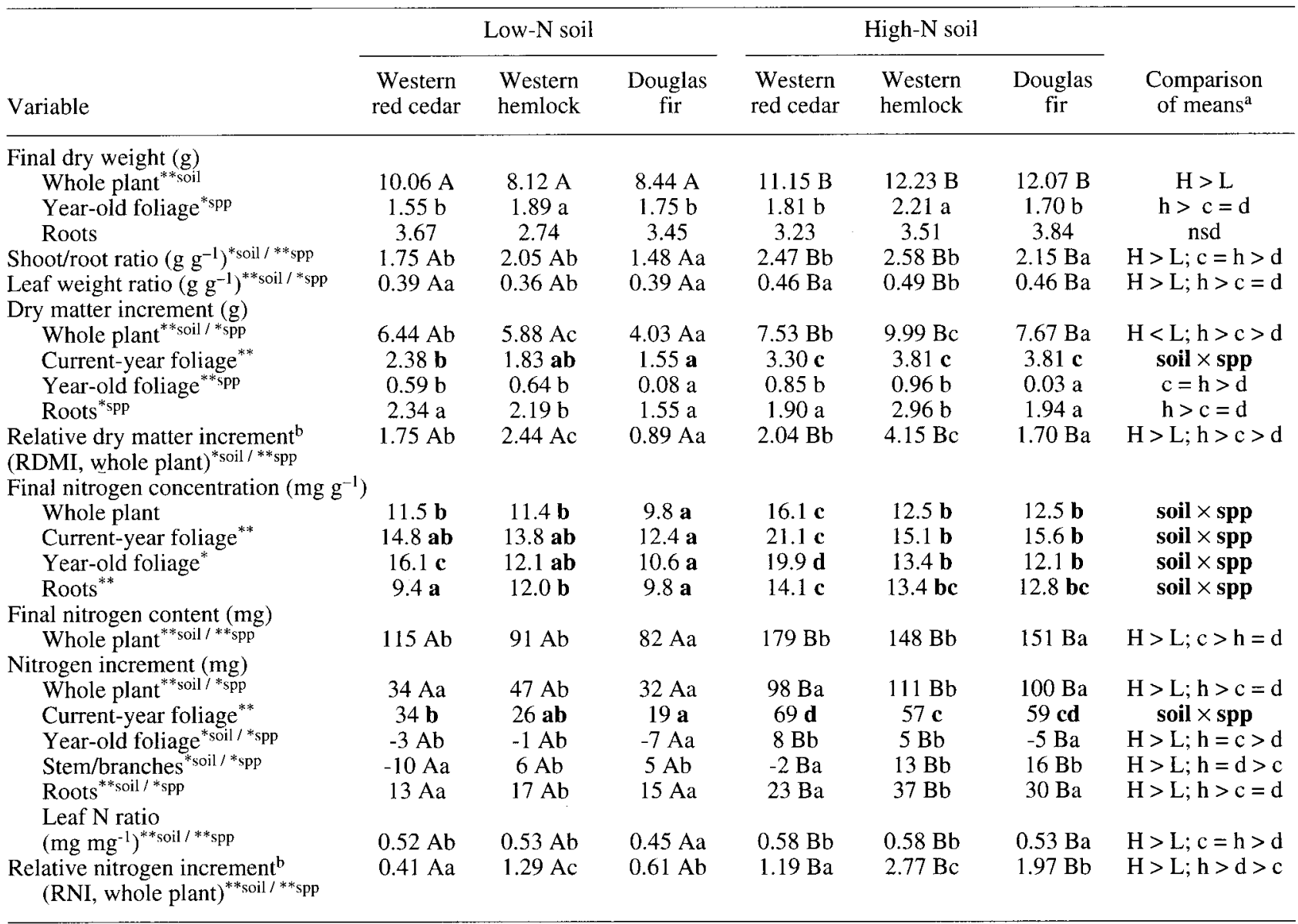

Values within a row followed by the same letter and case are not significantly different. Bold letters refer to statistically significant differences between means based on interaction of fixed effects (soil X species (PROC GLM in SAS [30])). Means of variables without bold letters were not affected by the soil by species interaction, but were found to be significantly different based on the single factor effects (upper case $=$ soil effect; lower case $=$ species effect. ${ }^{* *} P<0.01 ; * P<0.05$ for soil and/or species effect).

${ }^{a}$ The comparison of means column indicates that either i) the interaction effect was statistically significant (soil $\times$ spp) or ii) one or both of the single factor effects was statistically significant $(\mathrm{L}=$ low-N soil, $\mathrm{H}=$ high-N soil; $\mathrm{c}=$ western red cedar, $\mathrm{h}=$ western hemlock; $d=\mathrm{Douglas}-\mathrm{fir})$.

${ }^{b}$ Relative dry matter (RDMI) and relative $\mathrm{N}$ increments (RNI): means of $\log _{e}\left(\right.$ final) $-\log _{e}$ (initial). Values have been back-transformed and 1 has been subtracted from the result to yield the percent increase in dry weight or $\mathrm{N}$ content relative to initial value.

\section{Discussion}

In each of the soils, western hemlock achieved the greatest RDMI of the three species and accumulated stem/branch and root masses at more than double the rates of the other two species (table IV). Despite $\mathrm{N}$ deficiency in the low-N soil, the $\mathrm{N}$ concentrations of the component tissues of western hemlock did not differ among soils (table III). In contrast, $\mathrm{N}$ concentrations of each component of western red cedar and Douglas fir were lower on the low-N than on the high-N soil (table
$I I I)$. These differences may be attributable directly to the high RDMI of the roots of western hemlock compared with those of western red cedar and Douglas fir (table $I V)$. If increased root RDMI was associated with an increase in the number or surface area of fine roots, the capacity of hemlock to acquire the less mobile $\mathrm{N}$ form $\mathrm{NH}_{4}{ }^{+}$may have been enhanced. Thus western hemlock's apparent preference for $\mathrm{NH}_{4}{ }^{+}$over $\mathrm{NO}_{3}{ }^{-}[21,32]$ may be due in part to differences in fine root production among the species (e.g. root surface area). The greater acquisition of nitrogen from low- $\mathrm{N}$ soil by western hemlock 
Table IV. Relative dry weight and nitrogen increments of conifer seedlings and their component tissues after 8 weeks.

\begin{tabular}{|c|c|c|c|}
\hline Variable & $\begin{array}{l}\text { Western } \\
\text { red cedar }\end{array}$ & $\begin{array}{l}\text { Western } \\
\text { hemlock }\end{array}$ & $\begin{array}{l}\text { Douglas } \\
\text { fir }\end{array}$ \\
\hline \multicolumn{4}{|c|}{ Relative dry-matter increment (RDMI): a } \\
\hline Whole seedling** & $1.89 \mathrm{~b}$ & $3.21 \mathrm{a}$ & $1.26 \mathrm{~b}$ \\
\hline Foliage: all age classes ${ }^{* *}$ & $3.59 \mathrm{a}$ & $2.62 \mathrm{a}$ & $1.52 \mathrm{~b}$ \\
\hline Foliage: year-old ${ }^{* *}$ & $0.69 \mathrm{a}$ & $0.57 \mathrm{a}$ & $0.02 \mathrm{~b}$ \\
\hline Stem/branch ${ }^{* *}$ & $0.93 \mathrm{~b}$ & $3.52 \mathrm{a}$ & $1.49 \mathrm{~b}$ \\
\hline $\operatorname{Roots}^{* *}$ & $1.56 \mathrm{~b}$ & $4.21 \mathrm{a}$ & $0.89 \mathrm{c}$ \\
\hline \multicolumn{4}{|l|}{ Relative $\mathrm{N}$ increment $(\mathrm{RNI}):^{\mathrm{a}}$} \\
\hline Whole seedling ${ }^{* *}$ & $0.76 \mathrm{c}$ & $1.94 \mathrm{a}$ & $1.19 \mathrm{~b}$ \\
\hline Shoot $^{* *}$ & $0.74 \mathbf{b}$ & $1.59 \mathrm{a}$ & $1.22 \mathrm{a}$ \\
\hline Foliage: all age classes ${ }^{* *}$ & $1.77 \mathrm{a}$ & $1.57 \mathrm{a}$ & $1.14 \mathrm{~b}$ \\
\hline Foliage: year-old ${ }^{* *}$ & $0.28 \mathrm{a}$ & $0.36 \mathrm{a}$ & $-0.24 b$ \\
\hline Stem/branch ${ }^{* * *}$ & $-0.22 \mathrm{c}$ & $1.21 \mathrm{~b}$ & $2.00 \mathrm{a}$ \\
\hline Roots $^{* *}$ & $0.77 \mathrm{~b}$ & $3.00 \mathrm{a}$ & $1.08 \mathrm{~b}$ \\
\hline
\end{tabular}

Different letters within a row indicate significant differences among species $(* P<0.050, * * P<0.010)$.

${ }^{a}$ Comparisons of means are based on results of analyses using PROC MIXED [30] with transformed data $\left(\log _{e}\right) \cdot \operatorname{Means}_{\text {of }} \log _{e}($ final $)-\log _{e}($ initial $)$ values have been back-transformed and 1 has been subtracted from the result to yield the percent increase in dry weight or $\mathrm{N}$ content relative to initial value.

(table III) is consistent with the more frequent occurrence of this species on nutrient-poor sites [22, 28].

Our results seem to contradict those of others who reported that western hemlock had a slower growth rate and was less responsive to increased $\mathrm{N}$ availability than western red cedar $[4,7,27]$. However, they are consistent with the results of Messier [22] and Chang et al. [9], who reported that western hemlock was more responsive than western red cedar to increased $\mathrm{N}$ availability; those studies were conducted on acid humus soils with high $\mathrm{C} / \mathrm{N}$ ratios and an apparent absence of $\mathrm{NO}_{3}^{-}$. The present study was conducted in a growth chamber under low light conditions. Taken together, the results from all of the aforementioned studies suggest that western hemlock may be less responsive than western red cedar or Douglas fir on richer soils, but better able to acquire $\mathrm{N}$ and accumulate dry matter under adverse conditions (e.g. low $\mathrm{N}$ availability [7]; high $\mathrm{C} / \mathrm{N}$ ratios $[8,9,22]$; low light (present study)).

Western red cedar performed well in the present study. However, the high $\mathrm{N}$ concentrations in the foliage and stem/branch components at the beginning of the study (table I) indicate that the $\mathrm{N}$ provided in the nursery exceeded western red cedar's requirements. The slight declines in the $\mathrm{N}$ content of year-old foliage and stem/branch components of western red cedar in the low$\mathrm{N}$ soil (table III) suggest that $\mathrm{N}$ was retranslocated out of these components to meet the $\mathrm{N}$ requirements of the current-year foliage and/or roots. Western red cedar may have overcome adverse effects associated with the low $\mathrm{N}$ availability and $\mathrm{NH}_{4}{ }^{+}$-dominant nutrition of the low- $\mathrm{N}$ soil by mobilizing this stored $\mathrm{N}$ (the $\mathrm{N}$ content of the year-old foliage and stem/branch components decreased even though the dry matter of the components increased) (table III). More than $25 \%$ of the increase in $\mathrm{N}$ content of the current-year foliage of red cedar in low- $\mathrm{N}$ soil may have been mobilized from stored reserves. This "extra" $\mathrm{N}$ may have been the primary reason that the RDMI for western red cedar in low-N soil was about $85 \%$ of the RDMI in high-N soil (table IV). Western hemlock and Douglas fir in low-N soil had only $60 \%$ of the RDMI of their high-N-soil counterparts (table $I V$ ). Regression analyses revealed that the relationship between total seedling $\mathrm{N}$ content and RDMI was much weaker for western red cedar $\left(r^{2}=0.40\right)$ than for western hemlock $\left(r^{2}=0.94\right)$ or Douglas fir $\left(r^{2}=0.82\right)$.

Hawkins and Henry [16] have reported that western red cedar seedlings grew more quickly than Douglas fir seedlings. Initial differences between the species used [16], including morphology (shoot/root ratios for western red cedar were two times greater than for Douglas fir) and nutritional status (initial $\mathrm{N}$ contents of $25 \mathrm{mg}$ (western red cedar) and $10 \mathrm{mg}$ (Douglas fir) per tree) may have had significant influence on first-year growth differences, as in the current study. Luxury accumulations of $\mathrm{N}$ in forest nurseries by western red cedar may be beneficial to maintaining favorable $\mathrm{N}$ status, but additional research is necessary to demonstrate that excess $\mathrm{N}$ is not detrimental to root production and survival in the field. High $\mathrm{N}$ concentrations in seedlings may lead to 
greater succulence and more severe responses to winter injury or summer drought.

The final $\mathrm{N}$ concentration of current-year foliage of Douglas fir in low-N soil (table III) was near the upper limit of "severe deficiency", as described by Ballard and Carter [2]. This result occurred despite a $20 \%$ advantage in initial $\mathrm{N}$ content (table I) and an RDMI that was $50 \%$ lower (table $I V$ ) than that of western hemlock. The low light level in the growth chamber was probably most responsible for the relatively poor performance of Douglas fir. However, Gijsman [13] found that 3-yearold Douglas fir seedlings planted in pots in a sandy soil amended in fall with 10,50 , or $100 \mathrm{mg} \mathrm{kg}^{-1}\left(\mathrm{NH}_{4}\right)_{2} \mathrm{SO}_{4}$ did not take up more $\mathrm{N}$ than controls. Nitrification was inhibited by applying $\mathrm{N}$-Serve (2-chloro-6-trichloromethylpyridine; Dow Chemical) to the soil, and Gijsman [13] concluded that $\mathrm{NH}_{4}{ }^{+}$alone was clearly inferior to $\mathrm{NO}_{3}{ }^{-}$alone or to $\mathrm{NH}_{4} \mathrm{NO}_{3}$ as a source of $\mathrm{N}$. Furthermore, soil water content in the present study was maintained near field capacity, which has been found to favor $\mathrm{NH}_{4}{ }^{+}$ uptake relative to $\mathrm{NO}_{3}{ }^{-}$uptake [14].

South [31] has questioned the validity of using relative increments to assess differences in growth. He suggested that dry matter increment be determined at multiple intervals of time during the growth period and that increments be plotted against the mean initial dry weight for all intervals. We did not determine dry weight or $\mathrm{N}$ content at multiple points in time; however, despite initial differences in dry weight and $\mathrm{N}$ content, the dry weights among species were not distinguishable at the conclusion of the 8-week growth period. The final whole plant dry weight means were 10.59 (western red cedar), 10.17 (western hemlock), and 10.26 (Douglas fir). Additional trials deploying seedlings of equal dry weight and $\mathrm{N}$ content or monitoring increments at multiple points in time [31] are necessary to confirm our conclusions about differences among the species.

Amendment of the two soils with $60 \mathrm{mg}\left(\mathrm{NH}_{4}\right)_{2} \mathrm{SO}_{4}{ }^{-}$ $\mathrm{N} \mathrm{kg}^{-1}$ did not affect seedling growth. In fact, less than $5 \%$ of the $\mathrm{N}$ applied was accounted for in the seedling biomass (only $0.6 \mathrm{mg}$ (low-N soil) and $1.4 \mathrm{mg}$ (high- $\mathrm{N}$ soil) of additional $\mathrm{N}$ uptake per pot). The current study may not have been of sufficient duration to realize any growth effects of $\mathrm{N}$ addition. Kelsey et al. [20] reported that differences in height and stem diameter growth were not apparent among unamended and $\mathrm{N}$-amended seedlings during the first 8-10 weeks after bud-break. In addition, the amount of $\mathrm{N}$ applied may not have been great enough to effect a response. Added $\mathrm{N}$ was immobilized by the soil biomass in our soil incubation trial; only $30 \%$ of the added $\left(\mathrm{NH}_{4}\right)_{2} \mathrm{SO}_{4}-\mathrm{N}$ was mineralized (table II).
In the current study, soil $\mathrm{N}$ availability exerted a significant influence on growth as seedlings planted in low$\mathrm{N}$ soil accumulated only $53-85 \%$ of the dry matter that their high- $\mathrm{N}$-soil counterparts accumulated (table III). The amount of $\mathrm{N}$ retranslocated was not controlled by seedling growth rate (counter to [26]), as low-N-grown seedlings grew more slowly than high-N-grown seedlings but retranslocated greater quantities of $\mathrm{N}$ from the year-old foliage (western red cedar and Douglas fir) and stem/branch (western red cedar) components. Similarly, Hawkins and Henry [16] observed no net retranslocation in western red cedar and Douglas fir when $\mathrm{N}$ supply was high, but increased net retranslocation associated with high initial tissue $\mathrm{N}$ concentrate when current $\mathrm{N}$ supply was inadequate.

In the current study, western hemlock achieved the highest growth rates (RDMI), but was found to have retranslocated virtually no $\mathrm{N}$ from older tissues (table III). Differences between species with regard to retranslocation were not wholly associated with initial $\mathrm{N}$ content. A significant quantity of $\mathrm{N}$ was mobilized from the stem/branch component of the initially $\mathrm{N}$-enriched western red cedar, particularly in the low- $\mathrm{N}$ soil. However, the year-old foliage of Douglas fir retranslocated greater amounts of $\mathrm{N}$ (table $I I I$ ) despite having the lowest initial $\mathrm{N}$ concentration of the three species (table $I$ ). Our results indicate that on $\mathrm{N}$-limited soils, remobilization may be an important component of internal $\mathrm{N}$ cycling for western red cedar and Douglas fir, but not for western hemlock. Overall, the dynamics of retranslocation in this study seem to have been controlled primarily by species-specific differences, with soil $\mathrm{N}$ availability exerting a strong secondary influence. At least a portion of the "species-specific differences" may have been attributable to initial differences in leaf/weight ratio (table I). Our data are only partially consistent with the hypothesis that retranslocation varies with species, the relative availability of soil nutrients, and growth rate [17, $18,25,26]$.

\section{Conclusions}

This study provides a first direct comparison of seedling growth of three important Pacific Northwest conifers on forest soils. Clearly, western hemlock accumulated more $\mathrm{N}$ and had greater RDMI than western red cedar or Douglas fir; this result may reflect either hemlock's greater efficiency in acquiring inorganic $\mathrm{N}$ or an inherently greater growth rate under low light conditions. Western red cedar performed surprisingly well in low- $\mathrm{N}$ soil despite apparent $\mathrm{NH}_{4}$-dominant nutrition. The results seem to contradict those of Krajina et al. [21]; 
however, the initially high $\mathrm{N}$ content of the red cedar used in the current study may have obscured potentially negative effects of $\mathrm{NH}_{4}^{+}$nutrition; RNI was lower than for the other two species. The performance of western hemlock in low-N soil, compared with the performance of the other two species and with its own performance in high-N soil, supports the conclusions of Krajina et al. [21] and van den Driessche [34] that hemlock has greater tolerance for $\mathrm{NH}_{4}^{+}$. The results may be attributable to more prolific root development by western hemlock in soils where $\mathrm{N}$ is available exclusively as $\mathrm{NH}_{4}{ }^{+}$. Further study should be directed toward assessing root dynamics in response to $\mathrm{N}$ form.

On the basis of this study, we suggest that western hemlock may be the best option among the three species when planting seedlings to $\mathrm{N}$-limited forest sites in the Western Hemlock Zone. In this study, Douglas fir seemed to be the species least tolerant of low-N soil (note total plant RDMI of 0.89 ). These results were probably exacerbated by low light levels in the growth chamber and by the low initial $\mathrm{N}$ content of the Douglas fir seedlings. Comparisons under full-sun conditions are necessary to clearly assess differences among the species in $\mathrm{N}$-form preferences. Inherent differences in growth rate and nutrient acquisition should be evaluated at multiple intervals [31] and/or for seedlings of equivalent initial dry weight, leaf weight, and leaf $\mathrm{N}$ ratios.

Acknowledgements: This research was supported by the Department of Forest Resources and the Department of Forest Science at Oregon State University. Special thanks are due to Ron Haverlandt (Cavenham Forest Industries) for supplying the seedlings and Bud Graham for planting assistance. Jane Thomas and four anonymous referees provided valuable insights in revising this manuscript. Kermit Cromack, Jr, Dave Myrold, Tim Righetti, and Tim Schowalter reviewed earlier drafts of this article.

\section{References}

[1] Alban D.H., The influence of western hemlock and western red cedar on soil properties, Soil Sci. Soc. Am. Proc. 33 (1969) 453-457.

[2] Ballard T.M., Carter R.E., Evaluating forest stand nutrient status, B.C. Min. For. Land Manage. Rep. 20, 1985.

[3] Bedell J.P., Chalot M., Gamier A., Botton B., Effects of nitrogen source on growth and activity of nitrogen-assimilating enzymes in Douglas fir seedlings, Tree Physiol. 19 (1999) 205-210.

[4] Bledsoe C.S., Zasoski R.J., Seedling physiology of eight tree species grown in sludge-amended soils, in: Bledsoe C.S. (Ed.), Municipal Sludge Application to Pacific Northwest
Forest Lands, College of Forest Resources, University of Washington, Seattle, WA, 1981, pp. 93-100.

[5] Bowlsby C.C., Swanson R.C., Soil survey of Tillamook Area, Oregon. U.S. Soil Conserv. Serv., Soil Survey Series 1957, No. 18, 1964.

[6] Bremner J.M., Mulvaney C.S., Nitrogen total, in: Page A.L., Miller R.H., Keeney D.R. (Eds.), Methods of Soil Analysis. Part 2, Agronomy 9 (1982) 595-624.

[7] Brown K.R., Thompson W.A., Weetman G.F., Effects of $\mathrm{N}$ addition rates on the productivity of Picea sitchensis, Thuja plicata, and Tsuga heterophylla seedlings, Trees 10 (1996) 189-197.

[8] Chang S.X., Preston C.M., McCullough K., Weetman G.F., Barker J., Effect of understory competition on distribution and recovery of ${ }^{15} \mathrm{~N}$ applied to a western red cedar- western hemlock clear-cut site, Can. J. For. Res. 26 (1996) 313-321.

[9] Chang S.X., Weetman G.F., Preston C.M., Understory competition effect on tree growth and biomass allocation on a coastal old-growth forest cutover site in British Columbia, For. Ecol. Manage. 83 (1996) 1-11.

[10] Corliss J.F., Dyrness C.T., A detailed soil-vegetation survey of the Alsea area in the Oregon Coast Range, in: Youngberg C.T. (Ed.), Forest-Soil Relationships in North America, Papers, 2nd N. Am. For. Soils Conf., Oregon State University Press, Corvallis, OR, 1965, pp. 457-483.

[11] Curtis R.O., Reukema D.L., Crown development and site estimates in a Douglas fir plantation spacing test, For. Sci. 16 (1970) 287-301.

[12] Daubenmire R., Nutrient content of leaf litter of trees in the northern Rocky Mountains, Ecology 34 (1953) 786-793.

[13] Gijsman A.J., Nitrogen nutrition of Douglas fir (Pseudotsuga menziesii) on strongly acid sandy soil: I. Growth, nutrient uptake and ionic balance, Plant Soil 126 (1990) 53-61.

[14] Gijsman A.J., Soil water content as a key factor determining the source of nitrogen $\left(\mathrm{NH}_{4}{ }^{+}\right.$or $\left.\mathrm{NO}_{3}^{-}\right)$absorbed by Douglas fir (Pseudotsuga menziesii) and the pattern of rhizosphere $\mathrm{pH}$ along its roots, Can. J. For. Res. 21 (1991) 616-625.

[15] Graff J.E., Jr, Hermann R.K., Zaerr J.B., Ionic balance and organic acids in western redcedar, western hemlock, and Douglas fir seedlings grown in low- and high-N soils, Can. J. For. Res. 29 (1999) 669-678.

[16] Hawkins B.J., Henry G., Nutrition and bud removal affect biomass and nutrient allocation in Douglas fir and western redcedar, Tree Physiol. 19 (1999) 197-203.

[17] Hawkins B.J., Henry G., Kiiskila S.B.R., Biomass and nutrient allocation in Douglas fir and amabilis fir seedlings: influence of growth rate and nutrition, Tree Physiol. 18 (1998) 803-810.

[18] Hawkins B.J., Henry G., Kiiskila S.B.R., Biomass and nutrient allocation in Douglas fir and amabilis fir seedlings: influence of growth rate and temperature, Tree Physiol. 19 (1999) 59-63.

[19] Horneck D.A., Hart J.M., Topper K., Koepsell B., Methods of soil analysis used in the soil testing laboratory at 
Oregon State University, Agricultural Experiment Station, Oregon State University, Corvallis, OR, 1989.

[20] Kelsey R.G., Joseph G., Gerson E.A., Ethanol synthesis, nitrogen, carbohydrates, and growth in tissues from nitrogen fertilized Pseudotsuga menziesii (Mirb.) Franco and Pinus ponderosa Dougl. ex Laws. seedlings, Trees 13 (1998) $103-111$.

[21] Krajina V.J., Madoc-Jones S., Mellor G., Ammonium and nitrate in the nitrogen economy of some conifers growing in Douglas fir communities of the Pacific North-West of America, Soil Biol. Biochem. 5 (1973) 143-147.

[22] Messier C., Factors limiting early growth of western redcedar, western hemlock, and Sitka spruce seedlings on ericaceous-dominated clearcut sites in coastal British Columbia, For. Ecol. Manage. 60 (1993) 181-206.

[23] Messier C., Keenan R., Kimmins J.P., The effects of soil mixing on soil nutrient status, recovery of competing vegetation and conifer growth on cedar-hemlock cutovers in coastal British Columbia, New For. 9 (1995) 163-179.

[24] Milliken G.A., Johnson D.E., Analysis of Messy Data. Volume 1: Designed Experiments, Van Nostrand Reinhold, New York, NY, 1984.

[25] Munson A.D., Margolis H.A., Brand D.G., Seasonal nutrient dynamics in white pine and white spruce in response to environmental manipulation, Tree Physiol. 15 (1995) 141-149.
[26] Nambiar E.K.S., Fife D.N., Nutrient retranslocation in temperate conifers, Tree Physiol. 9 (1991) 185-207.

[27] Prescott C.E., McDonald M.A., Weetman G.F., Availability of $\mathrm{N}$ and $\mathrm{P}$ in the forest floors of adjacent stands of western redcedar- western hemlock and western hemlock-amabilis fir on northern Vancouver Island, Can. J. For. Res. 23 (1993) 605-610.

[28] Radwan M.A., DeBell D.S., Site index, growth and foliar composition relationships in western hemlock, For. Sci. 26 (1980) 283-290.

[29] Radwan M.A., Harrington C.A., Foliar chemical concentrations, growth, and site productivity relations in western red cedar, Can. J. For. Res. 16 (1986) 1069-1075.

[30] SAS Institute Inc., SAS/STAT Guide for Personal Computers, Version 6 edition, Cary, NC, 1987.

[31] South D.B., Relative growth rates: a critique, South African For. J. 173 (1995) 43-48.

[32] Turner D.P., Franz E.H., The influence of western hemlock and western redcedar on microbial numbers, nitrogen mineralization and nitrification, Plant Soil 88 (1985) 259-267.

[33] Turner D.P., Sollins P., Leuking M., Rudd N., Availability and uptake of inorganic nitrogen in a mixed oldgrowth coniferous forest, Plant Soil 148 (1993) 163-174.

[34] van den Driessche R., Response of conifer seedlings to nitrate and ammonium sources of nitrogen, Plant Soil 34 (1985) 421-439. 